\title{
Cluster of differentiation 14 gene polymorphism and its association with incidence of clinical mastitis in Karan fries cattle
}

\author{
A. Sakthivel Selvan, I. D. Gupta, A. Verma, M. V. Chaudhari and V. Kumar
}

Molecular Genetics Lab, Dairy Cattle Breeding Division, National Dairy Research Institute, Karnal - 132 001, Haryana, India. Corresponding author: I. D. Gupta, e-mail: idgupta1959@gmail.com, ASS: drasakthivel1987@gmail.com, AV: archana.ndri@gmail.com, MVC: mvet99@gmail.com, VK: vetvkt1986@gmail.com

Received: 06-08-2014, Revised: 04-11-2014, Accepted: 07-11-2014, Published Online: 04-12-2014

doi: 10.14202/vetworld.2014.1037-1040. How to cite this article: Selvan AS, Gupta ID, Verma A, Chaudhari MV, Kumar V (2014) Cluster of differentiation 14 gene polymorphism and its association with incidence of clinical mastitis in Karan fries cattle, Veterinary World 7(12): 1037-1040.

\begin{abstract}
Aim: The present study was undertaken with the objectives to characterize, identify DNA polymorphism in cluster of differentiation 14 (CD14) gene in Karan Fries (KF) cattle and to analyze association between genetic variants with incidence of clinical mastitis in National Dairy Research Institute (NDRI) herd, Karnal.

Materials and Methods: Genomic DNA was extracted using blood of randomly selected hundred KF lactating cattle by phenol-chloroform method. After checking its quality and quantity, polymerase chain reaction (PCR) was carried out using reported primers to amplify 832 base pair region covering nucleotide base position number 1012 to 1843 (part of promoter, 5'UTR, exon 1, intron 1 and part of exon 2) of bovine CD14 gene. The PCR amplified target product was purified, sequenced and further ClustalW analysis was done to align edited sequence with reported Bos taurus sequence (EU148610.1). The restriction fragment length polymorphism (RFLP) analysis was performed for each KF cow using HinfI restriction enzyme (RE). Cows were assigned genotypes obtained by PCR-RFLP analysis and association study was done using Chi-square $\left(\chi^{2}\right)$ test.

Results: After PCR amplification, DNA sequencing of amplicon confirmed the 832 bases covering 1012 to 1843 nucleotide base position of bovine CD14 gene. ClustalW multiple sequence alignment program for DNA revealed six nucleotide changes in KF cows at positions T1117D, T1239G, T1291C, G1359C, G1361A, and G1811A. Cows were also screened using PCR-RFLP with HinfI RE, which revealed three genotypes CC, CD and DD that differed significantly regarding mastitis incidence. Within CC genotype, $72.73 \%$ of cows were in a mastitis non-affected group whereas, those in CD and DD genotypes $69.44 \%$ and $60.38 \%$ respectively were mastitis affected.
\end{abstract}

Conclusion: KF cows with allele C of CD14 gene were less susceptibility to mastitis compared with D allele.

Keywords: cluster of differentiation 14, Hinf1, Karan Fries, mastitis, restriction fragment length polymorphism, single nucleotide polymorphism.

\section{I ntroduction}

In India, crossbred cattle are gaining much importance being high milk producer compared to indigenous cattle, which could be observed by recent figures of county's milk production revealing that out of total cattle milk production more than half is contributed by crossbred cattle [1]. Karan Fries (KF) was developed by crossing Holstein Friesian bulls with Tharparkar cows at National Dairy Research Institute (NDRI) (Karnal) [2]. However, the major drawback of crossbred cows is their poor adaptability and susceptibility to infectious diseases especially mastitis when compared with indigenous cattle.

Genes play one of the major roles in disease resistance in bovine species [3-10]. Candidate genes such as BoLA-DRB3 [11, 12], FEZ [13], TLR4 [14, 15], CARD 15 [16, 17], cluster of differentiation 14 (CD14) [18-20] and many more genes are associated with mastitis resistance/susceptibility in

Copyright: The authors. This article is an open access article licensed under the terms of the Creative Commons Attributin License (http:// creative commons.org/licenses/by/2.0) which permits unrestricted use, distribution and reproduction in any medium, provided the work is properly cited. different cattle breeds. CD14 gene is one of the excellent candidates for mastitis resistance in cattle and has been mapped on BTA 7 [21]. Size of CD14 gene is $2630 \mathrm{bp}$ comprising of 2 exons and 1 intron. The total coding sequence of CD14 gene is 1122 bp that encodes 373 amino acids [18].

Since there is no report on CD14 gene polymorphism in KF cattle the present study was carried out with the objective to characterize and identify genetic polymorphism in CD14 gene and to explore association of this region with incidence of clinical mastitis in KF cattle.

\section{Materials and Methods \\ Ethical approval}

The experiment was approved by Institutional animal ethics committee

Blood samples of one hundred KF lactating cattle maintained at Livestock Research Centre of NDRI (Karnal) were collected from the cattle with history of incidences of clinical mastitis (affected $\geq$ once) and also the non-affected. Genomic DNA was extracted by phenol-chloroform method as described by Sambrook and Russel [22] with minor 
modifications. Quality of genomic DNA was checked on $0.6 \%$ agarose gel electrophoresis while its quantification was done using Nanodrop spectrophotometer method. Polymerase chain reaction (PCR) was carried out using CTTCCTGTTATAGCCCCTTTCC and CACGATACGTTACGGAGACTGA as forward and reverses gene-specific oligonucleotide primers, respectively, as reported by Ibeagha-Awemu et al. [18] to amplify 832 base pair region covering nucleotide base position number 1012-1843 (part of promoter, 5'UTR, exon 1, intron 1 and part of exon 2) of bovine CD14 gene. The PCR reaction mixture was incubated in thermal cycler initially at $94^{\circ} \mathrm{C}$ for $2 \mathrm{~min}$ followed by 34 cycles of $94^{\circ} \mathrm{C}$ for $30 \mathrm{~s}, 60^{\circ} \mathrm{C}$ for $30 \mathrm{~s}, 72^{\circ} \mathrm{C}$ for $40 \mathrm{~s}$, and a final extension of $72^{\circ} \mathrm{C}$ for $10 \mathrm{~min}$. The confirmation of each PCR amplification of desired target was done using $2 \%$ agarose gel electrophoresis. The PCR amplified target product was purified and sequenced by outsourcing (M/s. SciGenom Labs Pvt., Ltd.). The raw sequence was edited (BioEdit) and further ClustalW analysis was done to align edited sequence with reported $B$. taurus sequence (EU148610.1). The restriction fragment length polymorphism (RFLP) analysis was performed for each KF cow using HinfI restriction enzyme (RE). PCR products of each animal were digested with HinfI $\mathrm{RE}(0.4 \mathrm{ml})$ at $37^{\circ} \mathrm{C}$ for $16 \mathrm{~h}$. Fragments of RE digestion were separated on $2.5 \%$ agarose gel and photographed using gel documentation system. Cows were grouped as mastitis affected and not affected and were assigned genotypes obtained by PCR-RFLP analysis. Association study was done using the Chi-square $\left(\chi^{2}\right)$ test.

\section{Results and Discussion}

Genomic DNA was extracted from blood of 100 KF cows. Targeted 832 bp region (part of promoter, 5'UTR, exon 1, intron 1 and part of exon 2) of bovine CD14 gene from each DNA sample was amplified using specific primer pairs in thermal cycler (Figure-1).

DNA sequencing of the amplicon confirmed the 832 bases covering 1012-1843 nucleotide base position of bovine CD14 gene. Further, these nucleotide sequences of KF cows were compared with that of B. taurus (EU148610.1) using ClustalW multiple sequence alignment program for DNA and six nucleotide changes in KF cows at positions T1117D, T1239G, T1291C, G1359C, G1361A and G1811A

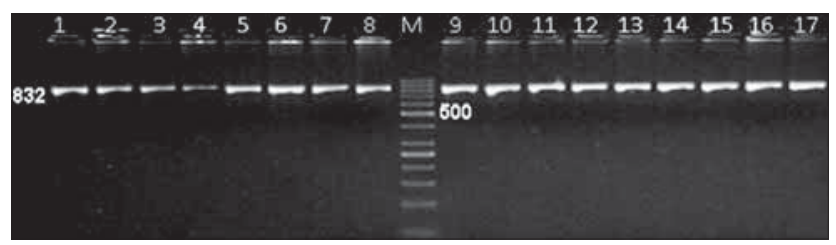

Figure-1: Polymerase chain reaction (PCR) product of 832 bp target region of cluster of differentiation 14 gene in Karan fries cows were observed. Out of these six single nucleotide polymorphisms (SNPs) three were for thiamine and three for guanine (Figures-2 and 3). All SNPs except at position 1117 base pair were similar to that observed by Kumar et al. [20] in Sahiwal (Bos indicus) cows.

\section{Association analysis of RFLP fragments of CD14} gene-targeted region with clinical mastitis

HinfI RE digestion of 832 bp PCR amplified product of KF CD14 gene exhibited five fragments of 47, 183, 225, 272 and $377 \mathrm{bp}$, resolving into three genotypes. Cows with band patterns 377, 272 and $183 \mathrm{bp}$ were assigned genotype CC while those with 377, 272, 225, 183 and 47 bp were assigned genotype CD and 377, 225, 183 and 47 bp as genotype DD (Figure-4). The DD genotype was highest followed by $\mathrm{CD}$ and $\mathrm{CC}$ with $0.53,0.36$ and 0.11 genotypic frequencies respectively in the studied population. The frequency of $\mathrm{D}$ allele was 0.71 and that of $\mathrm{C}$ was 0.29 . However, the findings are different from that of Kumar et. al. [20] where, he reported genotype CC and allele $\mathrm{C}$ with highest frequency for the same targeted region of $832 \mathrm{bp}$ of CD14 gene using HinfI RE in Sahiwal cows.

Chi-square $\left(\chi^{2}\right)$ analysis revealed that all three genotypes of KF cattle differ significantly regarding mastitis incidence. Within CC genotype, only $27.27 \%$

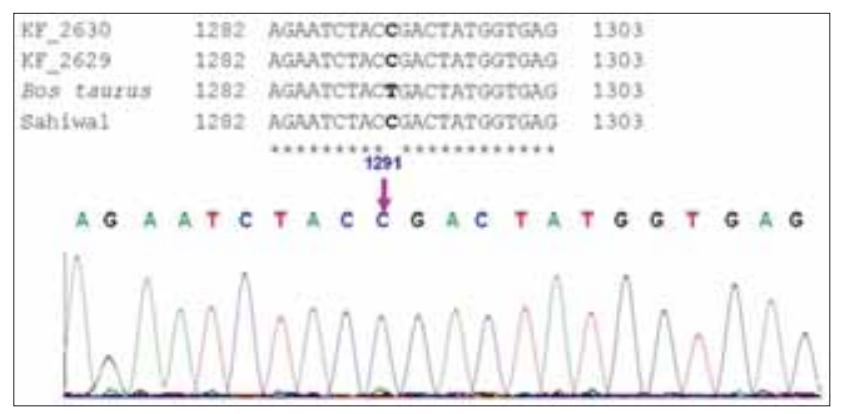

Figure-2: Chromatogram showing nucleotide change at position 1291(T>C)

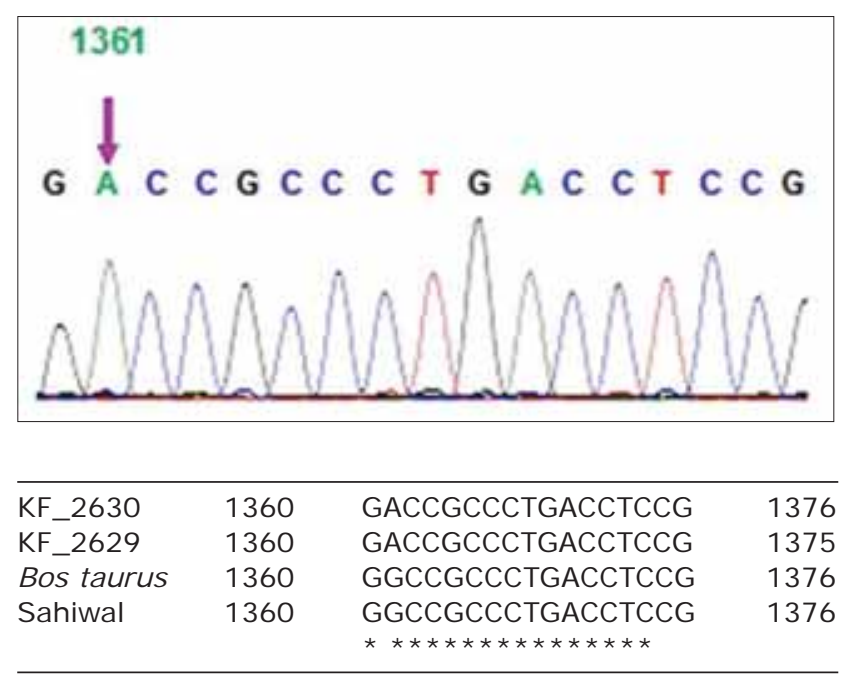

Figure-3: Chromatogram showing nucleotide change at position $1361(\mathrm{G}>\mathrm{A})$. 


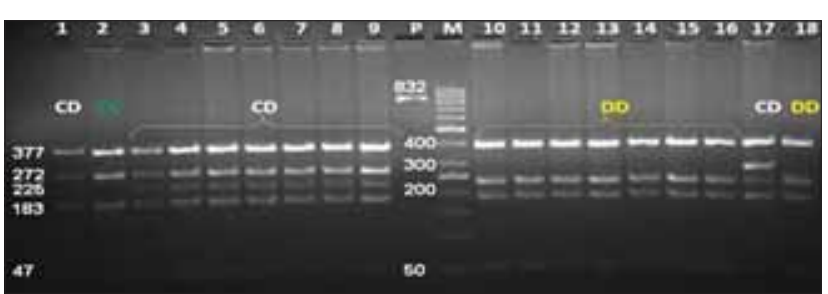

Figure-4: Polymerase chain reaction (PCR) restriction fragment length polymorphism analysis of 832 bp target region of cluster of differentiation 14 (CD14) using Hinfl restriction enzyme in Karan Fries cows. Lane 2: CC (372, 272 and $183 \mathrm{bp})$, Lane 1, 3-9, 17: CD $(377,272,225,183$, $47 \mathrm{bp})$, Lane 10-16, 18: DD (377, 225, 183, 47 bp), P: PCR product (832 bp), M: 50 bp DNA ladder

cows were mastitis affected, whereas, $69.44 \%$ and $60.38 \%$ cows were mastitis affected within CD and DD genotypes respectively. Hence, it is inferred that allele $\mathrm{C}$ is desired allele of CD 14 gene with respect to a lesser incidence of mastitis in KF cows.

\section{Conclusions}

The nucleotide sequencing of the targeted region of $832 \mathrm{bp}$ (part of the promoter, 5'UTR, exon 1 , intron 1 and part of exon 2) of bovine CD14 gene revealed six SNPs in KF cattle breed. PCRRFLP analysis of the same region showed three patterns with significant association with incidence of clinical mastitis.

\section{Author's Contributions}

IDG conceived and designed the work. ASS conducted experiment. ASS and MVC done analysis, association study and VK assisted in writing of the manuscript. IDG and AV helped in the revision of the manuscript. All authors read and approved the final manuscript.

\section{Acknowledgments}

The authors are thankful to Head, DCB Division for providing necessary research facilities. The authors also thankful to the Director (NDRI) for financial assistance provided during the research work.

\section{Competing I nterests}

The authors declare that they have no competing interest.

\section{References}

1. BAHS. (2012) Basic Animal Husbandry Statistics. Government of India, Ministry of Agriculture, Department of Animal Husbandry, Dairying and Fishries, Krishi Bhawan, New Delhi.

2. Gurnani, M., Sethi, R.K. and Nagarcenkar, R. (1986) Development of Karan Fries cattle at NDRI, Karnal. Dairy Information Bulletin No. 111.9. National Dairy Research Institute, Karnal, India: p1-2.

3. Shuster, D.E., Kehrli Jr, M.E., Ackermann, M.R. and Gilbert, R.O. (1992) Identification and prevalence of a genetic defect that causes leukocyte adhesion deficiency in Holstein cattle. Proc. Natl. Acad. Sci. USA, 89: 9225-9229.

4. Qureshi, S., Larivière, L., Sebastiani, G., Clermont, S., Skamene, E., Gros, P. and Malo, D. (1996) A high-resolution map in the chromosomal region surrounding the Lps locus. Genomics, 31: 283-294.

5. Maillard, J.C., Berthier, D., Chantal, I., Thevenon, S. and Sidibé, I. (2003) Selection assisted by BoLA-DR/DQ haplotype against susceptibility to bovine dermatophilosis. Genet. Sel. Evol, 35(1): 193-200.

6. Garcia-Briones, M.M., Russell, G.C., Oliver, R.A., Tami, C., Taboga, O., Carrillo, E., Palma, E.L., Sobrino, F. and Glass, E.J. (2000) Association of bovine DRB3 alleles with immune response to FMDV peptides and protection against viral challenge. Vaccine, 19: 1167-1171.

7. Takeda, H., Takami, M., Oguni, T., Tsuji, T., Yoneda, K., Sato, H., Ihara, N., Itoh, T., Kata, S.R. and Mishina, Y. (2002) Positional cloning of the gene LIMBIN responsible for bovine chondrodysplastic dwarfism. Proc. Natl. Acad. Sci., 99: 10549-10554.

8. Kumar, N., Mitra, A., Ganguly, I., Singh, R., Deb, S.M., Srivatsava, S.K. and Sharma, A. (2005) Lack of association of brucellosis resistance with (GT)(13) microsatellite allele at 3'UTR of NRAMP1 gene in Indian zebu (Bos indicus) and crossbred (Bos indicus $\times$ Bos taurus) cattle. Vet. Microbiol., 111: 139-143.

9. Pinedo, P.J., Donovan, A., Rae, O. and DeLapaz, J. (2009) Association between paratuberculosis infection and general immune status in dairy cattle. Proceedings International Association for Paratuberculosis. College of Veterinary Medicine, Minneapolis, USA. p127.

10. Juliarena, M.A., Poli, M., Ceriani, C., Sala, L., Rodríguez, E., Gutierrez, S., Dolcini, G., Odeon, A. and Esteban, E.N. (2009) Antibody response against three widespread bovine viruses is not impaired in Holstein cattle bovine leukocyte antigen (BoLA) DRB3.2 carrying alleles associated with bovine leukemia virus resistance. J. Dairy. Sci., 92(1): 375-381.

11. Nascimento, C.S., Machado, A.M., Martinez, L.M., Silva, M.V.G., Martins, M.F. and Campos, A.L. (2006) Association of the bovine major histocompatibility complex (BoLA) BoLA-DRB3 gene with fat and protein production and somatic cell score in Brazilian Gyr dairy cattle (Bos indicus). Genet. Mol. Biol., 29(4): 641-647.

12. Rupp, R., Hernandez, A. and Mallard, B.A. (2007) Association of bovine leukocyte antigen (BoLA) DRB 3.2 with immune response, mastitis and production and type traits in Canadian Holsteins. J. Dairy. Sci., 90: 1029-1038.

13. Sugimoto, M., Fujikawa, A., Womack, J.E. and Sugimoto, Y. (2006) Evidence that bovine forebrain embryonic zinc finger-like gene influences immune response associated with mastitis resistance. Proc. Natl. Acad. Sci., 103(17): 6454-6459.

14. Wang, X., Xu, S., Xue, S., Ren, H. and Chen, J. (2007) Genetic polymorphism of TLR4 gene and correlation with mastitis in cattle. J. Genet. Genomics, 34(5): 406-412.

15. Wang, X., Xu, S., Xue, G., Li, J., Ren, H. and Luoren, Z. (2008) Cloning and SNP screening of the TLR4 gene and the association between its polymorphism and somatic cell score in dairy cattle. South. Afr. J. Anim. Sci, 38(2): 101-109.

16. Pant, S.D., Schenkel, F.S., Leyva-Baca, I., Sharma, B.S. and Karrow, N.A. (2007) Identification of single nucleotide polymorphisms in bovine CARD15 and their associations with health and production traits in Canadian Holsteins. BMC Genomics, 8: 421.

17. Soumya, N.P., Gupta, I.D., Verma, A., Raja, K.N., Chauhan, I. and Chaudhari, M.V. (2013) Identification of CARD-15 gene polymorphism in Sahiwal cattle. Indian $J$. Anim. Res., 47(1): 83-86.

18. Ibeagha-Awemu, E.M., Lee, J.W. and Ibeagha, A.E. (2008) Bovine CD14 gene characterization and relationship between polymorphisms and surface expression on monocytes and polymorphonuclear neutrophils. BMC Genet., 9: 50-60.

19. Beecher, C., Daly, M., Childs, S., Berry, D.P., Magee, DA., McCarthy, T.V. and, Giblin, L. (2010) Polymorphisms in 
bovine immune genes and their associations with somatic cell count and milk production in dairy cattle. BMC Genet., 11: 99-108.

20. Kumar, V., Gupta, I.D., Verma, A., Kumar, S.R. and Chaudhari M.V. (2014) CD14 gene polymorphism using HinfI restriction enzyme and its association with mastitis in Sahiwal cattle. Indian J. Anim. Res., 48: 11-13.
21. Ogorevc, J., Kunej, T., Razpet, A. and Dovč, P. (2009) Database of cattle candidate genes and genetic markers for milk production and mastitis. Anim. Genet., 40: 832-851.

22. Sambrook, J. and Russell, D.W. (1989) Preparation and analysis of eukaryotic DNA. In: Molecular Cloning: A Laboratory Manual. $3^{\text {rd }}$ ed. Cold Spring Harbor Laboratory Press, New York. p6.1-6.62.

$* * * * * * * *$ 